\title{
Relationship of Genetic Variation to Population Size in Wildlife
}

\author{
RICHARD FRANKHAM
}

Key Centre for Biodiversity and Bioresources, Macquarie University, Sydney NSW 2109, Australia, email rfrankha@rna.bio.mq.edu.au

\begin{abstract}
Genetic diversity is one of three levels of biological diversity requiring conservation. Genetic theory predicts that levels of genetic variation should increase with effective population size. Soulé (1976) compiled the first convincing evidence that levels of genetic variation in wildlife were related to population size, but tbis issue remains controversial. The hypothesis that genetic variation is related to population size leads to the following predictions: (1) genetic variation within species should be related to population size; (2) genetic variation within species should be related to island size; (3) genetic variation should be related to population size within taxonomic groups; (4) widespread species sbould bave more genetic variation than restricted species; (5) genetic variation in animals should be negatively correlated witb body size; (6) genetic variation should be negatively correlated with rate of chromosome evolution; (7) genetic variation across species should be related to population size; (8) vertebrates should bave less genetic variation than invertebrates or plants; (9) island populations sbould bave less genetic variation tban mainland populations; and (10) endangered species should bave less genetic variation than nonendangered species. Empirical observations support all these bypotbeses. There can be no doubt that genetic variation is related to population size, as Soule proposed. Small population size reduces the evolutionary potential of wildife species.
\end{abstract}

La Relación Entre la Variacion Genética y el Tamaño Poblacional en Vida Silvestre

Resumen: La diversidad genética es uno de los tres niveles de diversidad biológica que requieren ser conservados. La teoría genética predice que los niveles de variación genética se incrementan con el tamano de la población efectiva. Soule (1976) reunió la primera evidencta convincente de que los niveles de variación genética en la fauna silvestre se relacionaban con el tamaño de sus poblaciones. Sin embargo, este tema sigue siendo controversial. La bipótesis de que la variación genética se relaciona con el tamaño poblacional conduce a las siguientes predicciones (1) la variación genética intraespecífica debe relacionarse con el tamaño de la población, (2) la variación genética intraespecifica debe relacionarse con el tamaño de la isle, (3) la variacion genética debe relacionarse con el tamaño poblacional dentro de grupos taxonámicos, (4) especies ampliamente distribuidas deben tener mayor variación genética que especies de distribución restringida, (5) la variación genética en animales debe tener una correlación negative con el tamaño del cuerpo, (6) la variación genética debe correlacionarse negativamente con la tasa de evolución cromosómica, (7) la variación genética intraespecifica debe relacionarse con el tamaño de la población, (8) los vertebrados deben tener menos variación genética que los invertebrados o plantas, (9) poblaciones insulares deben tener menos vartación genética que poblaciones continentales, (10) especies amenazadas deben tener menos variación genética que especies no amenazadas. Todas estas bipótesis están sustentadas por observaciones empíricas. Como propuso Soulé, no bay duda de que la variación genética se relaciona con el tamaño de la población. El tamaño pequeño de una población reduce el potencial evolutivo de las especies de fauna silvestre.

Paper submitted August 29, 1995; revised manuscript accepted June 21, 1996.

1500

Conservation Biology, Pages 1500-1508

Volume 10, No. 6, December 1996 


\section{Introduction}

Conservation of genetic diversity is a fundamental concern in conservation biology. Genetic variation is the raw material for evolutionary change within wildlife populations. It allows populations to evolve in response to environmental change, whether that be new or changed diseases, pests, parasites, competitors or predators or greenhouse warming, ozone layer depletion, or pollution. Consequently, the World Conservation Union has recognized genetic diversity as one of three levels of biological diversity requiring conservation (McNeely et al. 1990).

The level of genetic variation within a species represents a balance between mutation, drift, and natural selection. Genetic variation is generated by mutation and is lost from populations by genetic drift due to finite population size. Natural selection may either erode genetic variation by leading to fixation of alleles or promote its retention as a result of balancing or diversifying selection. Loss of neutral genetic variation due to finite population size in the short to medium term approximates an exponential decay process, described as follows:

$$
H_{t} / H_{0}=\left[1-1 / 2 N_{e}\right]^{t} \sim e^{-t / 2 N_{e}},
$$

where $H_{t}$ is the heterozygosity at time $t, H_{0}$ the original heterozygosity, $N_{e}$ the effective population size, and $t$ the number of generations (Crow \& Kimura 1970). Because the variance of heterozygosity is expected to increase in small populations, this relationship can be obscured unless there are numerous genetic markers and many replicates. Allozyme variation declined according to Eq. 1 in replicated pedigreed populations of Drosophila melanogaster, with effective sizes between 25 and $\mathbf{5 0 0}$ maintained for $\mathbf{5 0}$ generations (Montgomery et al., in preparation).

Additive genetic variation for quantitative characters should also decline according to Eq. 1 because it is directly proportional to heterozygosity (Falconer \& Mackay 1996). Quantitative genetic variation for bristle characters in $D$. melanogaster behaved as predicted by Eq. 1, declining with generations (Briscoe et al. 1992) and declining more rapidly in populations with lower effective population sizes (Frankham 1996a).

The predicted equilibrium heterozygosity $(H)$ between neutral mutation and genetic drift in the long term is given by Eq. 2 , and the effective number of alleles at equilibrium $\left(n_{e}\right)$ by Eq. 3 :

$$
\begin{gathered}
H=4 N_{e} \mu /\left[4 N_{e} \mu+1\right] \\
n_{e}=4 N_{e} \mu+1,
\end{gathered}
$$

where $\mu$ is the mutation rate for neutral alleles (Crow \& Kimura 1970). Equation 2 yields the sigmoid relationship between $H$ and $\log N_{e}$ shown in Fig. 1. Because mutation rates are similar across diploid eukaryotic species (Weaver \& Hedrick 1992), Eq. 2 predicts that heterozygosity will be related to the effective population size both across populations within species and across spe-

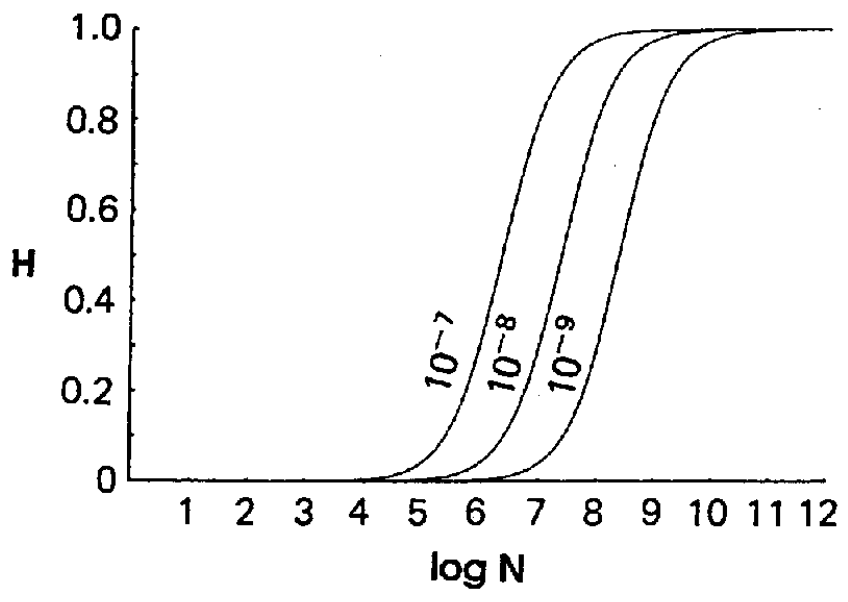

Figure 1. Predicted relationship between beterozygosity $(H)$ and logaritbm of effective population size (log $N)$ for tbree different neutral mutation rates according to Eq. 2 (after Soulé 1976).

cies. Provided that population size $(N)$ is correlated with $N_{e}$, and that current $N$ reflects past $N$, then a relationship between $H$ and $N$ similar to Fig. 1 is expected.

Surprisingly, empirical evidence on the relationship between population size and genetic variation in wildlife is equivocal. Soulé (1976) observed a strong positive correlation of 0.7 between heterozygosity and $\log N$ in animals, explaining approximately one-half of the variation in heterozygosity (Fig. 2). This is an example of Soulé's forte for mining the literature to great effect. Recognition of this important contribution has been sidetracked, largely because of the neutralist-selection controversy (see Kimura 1983; Gillespie 1991). Interestingly, Soule transcended this controversy, accepting that at least some allozyme loci were subject to balancing natural selection (Soulé 1980), while recognizing that small population size reduced genetic variation.

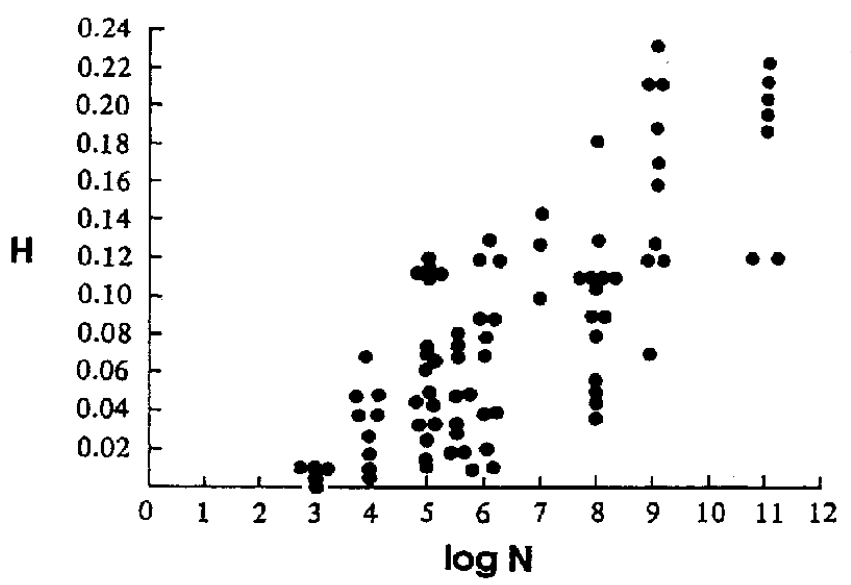

Figure 2. Correlation between beterozygosity (H) and logaritbm of populations size (log $N$ ) for animal specles, as given by Soule (1976). 
The reality of this relationship has been questioned. For example, Gillespie (1991) queried a similar relationship in data collected by Nei and Graur (1984). He noted that the lowest values of $H$ were mainly from carnivores and the highest values from Drosophila species, so that the observed difference might reflect different ecologies and different selective forces. Several studies of the relationship between heterozygosity and $\log N$ in plants have yielded nonsignificant relationships (Ellstrand \& Elam 1993). This could be due either to a lack of relationship or to a reflection of the noisy nature of the relationship due to large drift variance in small populations. This issue can be resolved only by analysis of data from many studies.

The strength of the relationship between genetic variation and population size is likely to vary for different categories of loci because they are subject to different intensities of selection. Selective forces on allozyme laci are weak (Kimura 1983; Gillespie 1991; Ohta 1992), with perhaps $50 \%$ of loci subject to weak selection favoring heterozygotes (Brookfield \& Sharp 1994). Noncoding DNA regions and synonymous mutations appear to be subject to little selection. Mitochondrial DNA is expected to be subject to selective sweeps because it codes for essential functions and shows little or no recombination. Direct evidence of selective differences among mtDNA haplotypes has been found in Drosopbila (MacRae \& Anderson 1988; Fos et al. 1990; Hutter \& Rand 1995). Natural selection on quantitative genetic variation is weak for characters peripheral to reproductive fitness and strong for reproductive fitness itself (Falconer \& Mackay 1996), although the intensify of the effect on individual loci is unclear because the number of loci over which selection is spread is unknown.

A correlation between heterozygosity and effective population size is expected for loci under heterozygote advantage selection in finite populations. The effect of heterozygote advantage on fixation probability depends on the equilibrium frequency of the alleles (Robertson 1962). Selection retards fixation for alleles with equilibrium frequencies in the $0.2-0.8$ range. Conversely, selection accelerates fixation for alleles with equilibrium frequencies outside this range. Hence, heterozygote advantage in finite populations will slow fixation for some alleles and accelerate it for others. Alleles subject to natural selection approach effective neutrality as the effective population size drops-when the selection coefficient drops below 1/2N $N_{e}$ (Wright 1931; Kimura 1983). The effect of selection on individual alleles detected by electrophoresis or DNA sequence is generally weak, so they are likely subject to genetic drift unless population sizes are very large (Robertson 1962; Kimura 1983; Ohta 1992; Satta et al. 1994). The relationship between genetic variation and population size should be strongest for neutral genetic markers and poorest for the most strongly selected markers; non-coding nuclear DNA should show the best relationship, followed by allo-zymes, quantitative genetic variation for peripheral characters, and mitochondrial DNA, with quantitative genetic variation for reproductive fitness characters showing the weakest relationship.

I tested predictions arising from the hypothesis that genetic variation is related to population size. In most cases population size data were not available, so correlates of population size such as island size, distribution (widespread versus restricted), body size, rate of chromosomal evolution (Lande 1979), and endangered versus nonendangered were used to extend the range of data that could be used. The following predictions were evaluated: (1) genetic variation within species will be related to population size; (2) genetic variation within species will be related to island size; (3) genetic variation among species will be related to population size within taxonomic groups; (4) widespread species will have more genetic variation than restricted species; (5) genetic variation in animals will be negatively correlated with body size; (6) genetic variation will be negatively related to rate of chromosome evolution; (7) genetic variation across species will be related to population size; (8) vertebrates will have less genetic variation than invertebrates or plants; (9) island populations should have less genetic variation than mainland populations; and (10) endangered species will have less genetic variation than nonendangered species.

\section{Data Analyses}

It has been traditional to correlate measures of genetic variation with $\log N$, following Soulé (1976). The justification for using this rather than alternative relationships is not clear. From Eq. 2, $H /(1-H)$ should be linearly related to $N_{e}$. Effective number of alleles per locus should be linearly related to $N_{e}$ according to Eq. 3 . To determine the most appropriate scales for presenting relationships between genetic variation and population size, $1 \mathrm{com}$ pared correlations of genetic variation measures with $N_{e}$, $\log N_{e}$, and $\left(\log N_{e}\right)^{2}$ using our Drosopbila melanogaster data. For gene diversity (expected heterozygosity), alleles per locus, and percent polymorphism, the highest correlation was with $\log N_{e}$. All three correlations involving observed heterozygosity were essentially identical (all 0.46). A similar comparison of the relationships between $H$ and $\log N$ and between $H /(1-H)$ and $N$ using the data of Nei and Graur (1984) also revealed a higher correlation for the former than the latter $(0.73$ versus 0.55). Consequently, I present correlations of genetic variation with $\log N$ or $\log$ island area, as have most authors.

I used all published data that could be located in testing the predictions. Where correlations between genetic variation and $\log N$ were not reported, they were computed from the data given. Correlations were computed between measures of genetic variation (gene diversity, observed heterozygosity, number of alleles per locus, and percent polymorphism) and the logarithm of popu- 
lation size $(N)$. The significance of each correlation was determined from the significance of the corresponding regression, with one-tailed tests because the predictions were directional. The data of Saura et al. (1973) was reanalyzed so that measures of genetic variation for the same 14 loci were used for all populations. Analyses of the data of Shapcott (1994) were restricted to Tasmanian mainland populations because there were significant island-mainland differences for some measures of genetic variation. Similar correlations were computed between genetic variation and logarithm of island size.

Over all data sets correlations are equaliy likely to be positive or negative under the null hypothesis that there is no correlation between genetic variation and population size (island area). Conversely, the alternative hypothesis of an association between genetic variation and population size predicts that correlations will be predominantly positive. I tested the number of positive and negative correlations for deviations from equality using a onetailed chi-square test. This represents a simple version of meta-analysis of the form already used in conservation biology by Ralls and Ballou (1983). Although more powerful statistical methods are now available for meta-anal- yses (Arnquist \& Wooster 1995), it is inconceivable that they would alter the overall conclusions of these analyses.

\section{Results}

Prediction 1. Genetic variation within species will be positively correlated with population size

The correlation between allozyme genetic variation $\left(H_{e}\right.$ or $H_{o}$ ) and logarithm of population size was positive in 22 of 23 studies within species of plants and animals (Table 1). This represents a highly significant excess of positive correlations $\left(x^{2}=19.17,1 d f, p<0.000025\right)$. All measures of allozyme genetic variation showed significant associations with $\log N$, as tested using sign tests. The average magnitude of the correlations between genetic variation and $\log N$ overall were not markedly lower than those found between genetic variation and $\log N_{e}$ in Drosopbila melanogaster. The DNA fingerprint variation was significantly correlated with $\log N$ in red squirrels ( $r=0.75, p=0.027$; Wauters et al. 1994) and nonsignificantly so in California Channel Island fox $(r=0.71, p=0.057$; Gilbert et al. 1990).

Table 1. Correlations between genetic variation and logarithm of population size."

\begin{tabular}{|c|c|c|c|c|c|c|c|}
\hline Species location & $\mathrm{H}_{\mathrm{c}}^{b}$ & $\mathbf{H}_{o}{ }^{c}$ & $\mathbf{A}$ & $\mathbf{P}$ & Range of $\mathrm{N}$ & $\mathbf{n}$ & Reference \\
\hline \multicolumn{8}{|l|}{ Mammals } \\
\hline Ovis canadensis & $0.89^{* *}$ & $0.72^{*}$ & $0.89^{* *}$ & $0.93^{* *}$ & $100-1146$ & 8 & FitzSimmons et al. 1995 \\
\hline Peromyscus maniculatus & - & 0.02 & $0.88^{* *}$ & $0.74^{*}$ & $b$ & $\mathbf{8}$ & Gill 1980 \\
\hline Thomomys botae & - & $0.69^{n *}$ & - & - & $c$ & 23 & Patton \& Yang 1977 \\
\hline \multicolumn{8}{|l|}{ Bird } \\
\hline $\begin{array}{l}\text { Ptciodes borelais } \\
\text { Insect }\end{array}$ & $0.48^{* *}$ & - & $0.83^{* *}$ & $0.51^{* *}$ & $4-1122$ & 26 & Stangel et al. 1992 \\
\hline $\begin{array}{l}\text { Pbilaenus spumaris } \\
\text { Plants }\end{array}$ & - & 0.34 & 0.34 & 0.27 & $90-30,000$ & 7 & Saura et al. 1973 \\
\hline Acacia anomala & 0.71 & 0.64 & $0.85^{*}$ & $0.74^{*}$ & $3-50$ & 6 & Coates 1988 \\
\hline Aconitum noveboracense & - & 0.13 & 0.24 & 0.32 & $15-10,000$ & 38 & Dixon \& May 1990 \\
\hline $\begin{array}{l}\text { Atherosperma moschatum } \\
\text { Eichbornia paniculata }\end{array}$ & 0.13 & 0.13 & 0.08 & 0.06 & $c$ & 16 & Shapcott 1994 \\
\hline Brazil & 一 & 0.20 & 0.15 & 0.17 & $8-5,000$ & 49 & Husband \& Barrett unpublished data \\
\hline Jamaica & - & 0.41 & $0.45^{*}$ & 0.40 & $5-2,000$ & 17 & \\
\hline Eucalyptus albens & $0.70^{* *}$ & $0.77^{* *}$ & $0.69^{* *}$ & $0.54^{* *}$ & $14-6,000$ & 22 & Prober \& Brown 1994 \\
\hline Eucalyptus caesia & 0.22 & - & $0.58^{*}$ & $0.48^{*}$ & $7-550$ & 13 & Moran \& Hopper 1983 \\
\hline Eucalyptus crucis & $0.62^{*}$ & $0.61^{*}$ & $0.71^{*}$ & $0.80^{*}$ & $4-300$ & 10 & Sampson et al. 1988 \\
\hline Eucalyptus parvifolia & 0.59 & 0.44 & 0.48 & -0.07 & $12-427$ & 8 & Prober et al. 1990 \\
\hline Eucalyptus pendens & -0.35 & -0.38 & -0.32 & 0.06 & $27-3,000$ & 7 & Moran \& Hopper 1987 \\
\hline Eucalyptus pulverulenta & 0.75 & 0.66 & $0.91^{*}$ & $0.98^{*}$ & $15->500$ & 4 & Peters et al. 1980 \\
\hline Gentiana pneumonantbe & 0.21 & 0.21 & 0.21 & $0.44^{* *}$ & $1-20,000$ & 25 & Raijmann et al. 1994 \\
\hline Halocarpus bidwilli & $0.94^{* *}$ & - & $0.89^{* *}$ & $0.89^{* *}$ & $20-400,000$ & 17 & Billington 1991 \\
\hline Salvia pratensis & 0.31 & 一 & $0.54^{*}$ & $0.62^{* *}$ & $5-1,500$ & 14 & Bijlsma et al. 1994 \\
\hline $\begin{array}{l}\text { Scabiosa columbaria } \\
\text { Silene regia }\end{array}$ & 0.49 & - & $0.82^{ \pm *}$ & $0.71^{* *}$ & $14-100,000$ & 12 & $\begin{array}{l}\text { Bijlsma et al. } 1994 \\
\text { Dolan } 1994\end{array}$ \\
\hline east & $0.71^{*}$ & - & - & 0.51 & $45-895$ & 9 & \\
\hline west & 0.14 & - & - & 0.21 & $41-1,302$ & 9 & \\
\hline Wasbingtonia filifera & 0.23 & 0.12 & - & $0.72^{*}$ & $1-82$ & 16 & McClenaghan \& Beauchamp 1986 \\
\hline Means & 0.46 & 0.36 & 0.54 & 0.50 & & & \\
\hline Drosopbila melanogaster & $0.56^{* *}$ & $0.46^{*}$ & $0.86^{* *}$ & $0.78^{* *}$ & $25-500$ & 23 & Montgomery et al. in preparation \\
\hline
\end{tabular}

${ }^{a}$ Genetic varlation for allozymes was charactertzed as gene diverstly $\left(\mathrm{H}_{c}\right.$ ), observed beterozygosity ( $\mathrm{H}_{i}$ ), allelic diversity (A), percentage of loci polymorpbic (P). $\mathrm{N}$ is population size and $\mathrm{n}$ is number of populations. ${ }^{\mathrm{p}}<0.05 ;{ }^{* *} \mathrm{p}<0.01$. Dasb indicates correlation not avallable.

${ }^{b}$ Relative population sizes were estimated from the product of island area and trapping success.

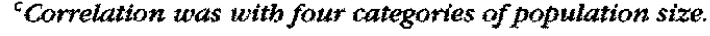


Quantitative genetic variation was related to population size, although there were far fewer data than for allozyme variation. Responses to artificial selection were greater in larger populations of Drosopbila melano gaster (Frankham et al. 1968; Jones et al. 1968; Hammond 1973; Franklin 1980; Weber 1990; Weber \& Diggins 1990), mice (Eisen 1975), and maize (Silvela et al. 1989). Phenotypic variation will reflect quantitative genetic variation if environmental variation is similar across populations. Bijlsma et al. (1994) reported positive correlations between phenotypic variation (averaged over a number of morphological, growth, and reproductive characteristics) and population size in two plant species $(0.92, p=0.0075$, in Salvia pratensis; $0.53, p=0.070$, in Scabiosa columbaria).

Prediction 2. Genetic variation will be positively correlated with island area

Significant positive correlations between genetic variation and logarithm of island area (or habitat island size) were reported in 16 of 19 studies involving mammals, birds, reptiles, and an insect (Table 2). This is a significant excess of positive correlations $\left(\chi^{2}=8.89, d f=1, p=\right.$ $0.0014)$. Eight studies reported significant correlations. The bird studies with negative correlations were based on very small sample sizes, $2-7$ for Camarbyncbus parvulus and 1-7 for Geospiza magnirostris.

Morphological variation showed a highly significant correlation of 0.81 with logarithm of island area in the lizard Uta stansburiana (Soule 1972), a highly significant correlation of 0.95 with $\log$ island area in the roof rat (Rattus rattus; Patton et al. 1975) and a nonsignificant correlation of 0.71 with log island area in the deer mouse (Peromyscus maniculatus; Aquadro \& Kilpatrick 1981).

Prediction 3. Genetic variation will be related to population size within taxonomic groups

Soulé (1976) reported positive relationships between heterozygosity and population size in lizards, fish, mammals, marine invertebrates, and Drosopbila. Nevo et al. (1984) found a significant relationship between heterozygosity and population size categories for vertebrates and plants but not for invertebrates. Within vertebrates there was a significant relationship for mammals and fish, but not for birds, reptiles, and amphibians. Cases with nonsignificant relationships were generally represented by few species. For vertebrates the population size category showed the highest correlation of $15 \mathrm{eco}$ logical, demographic, and life-history variables with both heterozygosity and percent polymorphism.

\section{Prediction 4. Genetic variation will be greater in species with wider ranges}

Populations within plant species with wider geographic ranges have higher allozyme variation (Table 3 ), and the widely distributed species have more overall allozyme variation (Hamrick \& Godt 1989). Further, allozyme vari-

Table 2. Correlations between genetic variation and logarithm of island size. ${ }^{a}$

\begin{tabular}{|c|c|c|c|c|c|c|}
\hline Species & $\mathrm{H}_{\mathrm{e}}$ & $\mathrm{H}_{\mathrm{o}}$ & $\mathbf{A}$ & $\mathbf{P}$ & $\mathbf{n}$ & Reference \\
\hline \multicolumn{7}{|l|}{ Mammals } \\
\hline Cynopterus bracbyotis & 0.03 & 0.01 & 0.25 & 0.25 & 6 & Peterson \& Heaney 1993 \\
\hline Haplonycteris fisberi & 0.15 & 0.42 & 0.09 & 0.15 & 6 & Peterson \& Heaney 1993 \\
\hline Macaca fascicularis & $0.86^{*}$ & - & - & $0.85^{*}$ & 7 & Kawamoto et al. 1988 \\
\hline Microtus pennsylvanicus & - & -0.40 & - & -0.60 & 7 & Kilpatrick 1981 \\
\hline Mus musculus & - & $0.55^{* *}$ & - & $0.77^{* *}$ & 19 & Kilpatrick 1981 \\
\hline Peromycus maniculatus & - & 0.40 & - & 0.35 & 7 & Kilpatrick 1981 \\
\hline Rattus rattus & - & $0.73^{*}$ & - & - & 8 & Patton 1984 \\
\hline \multicolumn{7}{|l|}{ Birds } \\
\hline Atalapetes brunneinuncha $a^{b, c}$ & - & 0.20 & - & - & 4 & Peterson et al. 1992 \\
\hline Camarbyncbus parvulus & - & -0.42 & - & - & 4 & Yang \& Patton 1981 \\
\hline Certbidea olivacea & - & $0.996^{*}$ & - & - & 4 & Patton 1984 \\
\hline Cblorospingus opbtbalmicus ${ }^{b, c}$ & - & 0.60 & - & - & 4 & Peterson et al. 1992 \\
\hline Geospiza fortis & - & 0.16 & - & - & 8 & Patton 1984 \\
\hline Geospiza fuliginosa & - & 0.24 & - & - & 10 & Patton 1984 \\
\hline Geospiza magnirostris & - & -0.62 & - & - & 4 & Yang \& Patton 1981 \\
\hline \multicolumn{7}{|l|}{ Reptiles } \\
\hline Anolis cristatellus & - & $0.60^{*}$ & - & - & 9 & Soulé 1980 \\
\hline Lacerta melisellensis & - & $0.76^{* *}$ & - & $0.70^{* *}$ & 12 & Gorman et al. 1975 \\
\hline Tracbydosaurus rugosus & 0.55 & 0.04 & 0.45 & 0.35 & 5 & Sarre et al. 1990 \\
\hline Uta stansburiana & - & $0.647^{\prime \prime}$ & - & $0.63^{* *}$ & 14 & Soulé \& Yang 1973 \\
\hline \multicolumn{7}{|l|}{ Insect } \\
\hline Parnassius mnemosyne & $0.83^{* *}$ & - & $0.83^{* *}$ & $0.52^{* *}$ & 24 & Descimon \& Napolitano 1993 \\
\hline
\end{tabular}

${ }^{a}$ Genetic variation for allozymes was characterized as gene diversity $\left(\mathrm{H}_{e}\right)$, observed beterozygosity $\left(\mathrm{H}_{\alpha}\right)$, allelic diversity (A) and percentage of loci polymorpbic (P). Number of islands is $\mathrm{n}$ " $\mathrm{p}<0.05$; ${ }^{* *} \mathrm{p}<0.01$.

${ }^{b}$ Habitat islands on the mainland.

'Rank correlation. 
ation was significantly lower in restricted versus widespread plant congeners (Karron 1987).

For all species and for vertebrates, Nevo et al. (1984) reported lower levels of genetic variation in endemics than narrow, regional, and widespread species, the latter three not differing significantly.

Prediction 5. Genetic variation in animals will be negatively correlated with body size

Large animals typically have smaller populations than small animals. Consequently, a negative correlation between body size and heterozygosity is predicted. Wooten and Smith (1985) reported a significant negative correlation between body size and allozyme heterozygosity in mammals.

Prediction 6. Genetic variation will be negatively correlated with rate of chromosome evolution

Lande (1979) predicted that rate of chromosome evolution would be negatively related to effective population size. Chromosomal heterozygotes typically show heterozygote disadvantage and unstable equilibria, such that low population sizes are required to fix new chromosomal mutations. Lande (1979) and Barrowclough and Shields (1984) have used rates of chromosome evolution to estimate species effective population sizes. Consequently, heterozygosity is predicted to be negatively correlated with rate of chromosome evolution. Coyne (1984) found a significant negative correlation between heterozygosity and rate of chromosome evolution in animals.

Prediction 7. Genetic variation will be positively correlated with population size across species

Soulé (1976) reported a correlation of 0.7 between heterozygosity and estimates of $\log N$ in animals (Fig. 2). This conclusion is supported by analyses of data presented by Nei and Graur (1984) on gene diversity (minimum 20 loci) and population sizes for 77 animal, plant,

Table 3. Geographic range and genetic variation within plant populations.*"

\begin{tabular}{lcccc} 
Geographtc range & $\mathrm{H}_{e}$ & $\mathrm{~A}$ & $\mathrm{P}$ & $\mathrm{n}$ \\
\hline Endemic & 0.063 & 1.39 & 26.3 & 100 \\
& $(0.006)$ & $(0.03)$ & $(2.1)$ & \\
Narrow & 0.105 & 1.45 & 30.6 & 115 \\
& $(0.009)$ & $(0.05)$ & $(2.2)$ & \\
Regional & 0.118 & 1.55 & 36.4 & 180 \\
& $(0.007)$ & $(0.04)$ & $(2.0)$ & \\
Widespread & 0.159 & 1.72 & 43.0 & 85 \\
& $(0.013)$ & $(0.07)$ & $(3.3)$ & \\
\hline
\end{tabular}

"Genetic variation for allozymes was characterized as gene diversity $\left(\mathrm{H}_{\mathrm{e}}\right)$, allelic diversity (A), and percentage of loci polymorpbic $(\mathrm{P})$. Standard errors are given in parentbeses and $\mathrm{n}$ is the number of species. (From Hamrick and Godt [19891).

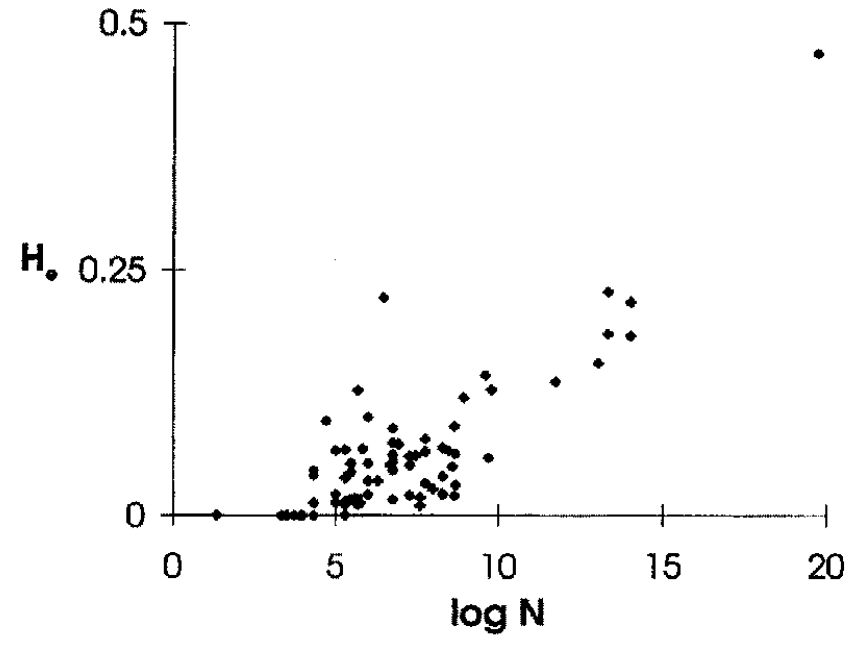

Figure 3. Relationship between gene diversity (expected diploid beterozygosity) $\left(H_{\theta}\right)$ and logarithm of populations size (log $N$ ) across species for the data of Nei and Graur (1984). The point for Eschericia coli to the extreme right is plotted against balf its population size because it is haploid.

and bacterial species (Fig. 3). The correlation between gene diversity and $\log N$ was 0.81 for the full data set and 0.73 with Escherichia coli omitted, very similar to the value reported by Soule (1976). Both correlations were highly significant. Nevo et al. (1984) reported higher allozyme variation in larger populations for all species, vertebrates and plants, but a nonsignificant relationship in invertebrates. Mitochondrial DNA nucleotide diversity showed a significant correlation of 0.45 with $\log N$ (females) $(\phi=0.032)$ for data on 18 populations of 12 species of vertebrates (Avise 1992).

\section{Prediction 8. Genetic variation will be lower in vertebrates than in invertebrates or plants}

For species in which allozyme genetic variation has been measured, vertebrates generally have lower population sizes than invertebrates or plants and so should have lower genetic variation. Nevo et al. (1984) showed that vertebrates had significantly lower levels of allozyme variation than invertebrates (heterozygosities of $0.054 \pm$ 0.0025 versus $0.100 \pm 0.0048$, respectively). The heterozygosity for vertebrates was significantly lower than the mean heterozygosity of $0.113 \pm 0.005$ for plant populations, reported by Hamrick and Godt (1989).

Prediction 9. Genetic variation should be less in island populations than mainland populations

Because island populations are typically smaller than mainland populations, they are predicted to have less genetic variation. A large and highly significant majority of island populations have less allozyme genetic variation than their mainland counterparts (165 of $203 \mathrm{com}$ - 
parisons; Frankham 1996b). Similar differences exist for other measures of genetic variation. Island endemic species showed lower allozyme variation than related mainland species in 34 of 38 cases.

\section{Prediction 10. Genetic variation will be lower in endangered species than nonendangered species}

By definition, endangered species typically have smaller populations than related nonendangered species and should have lower levels of genetic variation. Genetic variation was significantly reduced in endangered species compared with nonendangered species (Frankham 1995a), 32/38 endangered species being lower than their controls $\left(\chi^{2}=17.8,1 d f, p<0.0001\right)$.

\section{Discussion}

Nine of the 10 predictions of the hypothesis that genetic variation is related to population size were verified. The only prediction in which the evidence was equivocal was the taxonomic group; even here most comparisons were in the predicted direction. Consequently, there can be no doubt that genetic variation is related to population size; Soulé's (1976) conclusions have been amply vindicated. Data were most extensive for allozymes, but similar relationships were evident for mtDNA and for quantitative genetic variation.

It is implausible that reporting bias could explain all these positive associations because data were collected mostly for unrelated purposes. The Soulé (1976) and Nei and Graur (1984) analyses involved data collected in this way, as were the analyses for predictions relating to body size, rates of chromosome evolution, geographic range, endangered species, and the comparison of vertebrates versus invertebrates and plants. Only for predictions 1,2 , and 9 is reporting bias a potential problem. Even in these cases there seems to have been no impediment to reporting nonsignificant or negative correlations, or differences in the opposite direction to those predicted.

The positive correlations between genetic variation and population size variables probably represent causal relationships. Such a consistent relationship is predicted by population genetics theory. The only competing theory that predicts a similar relationship is diversifying selection favoring different genotypes in different habitats, and evidence for this is weak and inconsistent (Hedrick 1986). Widespread species would be expected to have greater niche diversity than more restricted species. Although this hypothesis is compatible with correlations between genetic variation and population size or island size within species, it stretches credibility to attribute all the correlations to this cause, especially those with body size and rates of chromosomal evolution and with the difference in genetic variation between vertebrates and invertebrates and plants. Alternative hypotheses for the relationship can be rejected for our controlled experiment in $D$. melanogaster. Mean correlations between genetic variation and $\log N$ within wildlife species, and that for all species, were not markedly lower than those observed in our controlled Drosophila experiment. Positive correlations were found within species, among species within taxonomic groups, and across all species.

Population size is arguably the most important variable explaining differences in allozyme variation. Logarithm of population size explained $49 \%$ or more of the variation in heterozygosity in the data sets of Soulé (1976) and Neve and Graur (1984), whereas Nevo et al. (1984) accounted for only $20 \%$ of the variation in heterozygosity with a suite of 15 ecological, demographic, and life-history variables, several themselves related to population size. Further, geographic range, a close correlate of $N$, was the most important variable explaining differences in heterozygosity among plant species and was equally important as breeding system in explaining differences in heterozygosity among plant populations (Hamrick \& Godt 1989). Conversely, in the analyses of Nevo et al. (1984), population size category was not one of the four significant explanatory variables for heterozygosity across all species. It was the most important explanatory variable for mammals and fish.

Soule (1976) pointed out that the relationship between heterozygosity and $\log N$ was not sigmoid as predicted by Eq. 2. Analyses of the Nei and Graur (1984) data support this: there was a higher correlation between $H$ and $\log N$ than between $H /(1-H)$ and $N(0.73$ versus 0.55 ), whereas the latter would give a higher correlation if the relationship was sigmoid. The predicted relationship is affected by natural selection, nonlinear relationships between $N_{e}$ and $N, N_{e}$ having narrower range than $N$, and populations not having sufficient time to reach equilibrium. Models with mildly deleterious and neutral mutations (the near neutral model) in finite populations give a near-linear relationship between heterozygosity and $\log N_{e}$, at least up to an $N_{e}$ of $10^{6}$ (Kimura 1983: 244). The overall relationship between heterozygosity and $\log N$ would not be possible if $N_{e} / N$ ratios varied widely among different species and taxa. Analyses of published estimates of $N_{e} / N$ ratios failed to detect significant differences among animal taxa (Frankham 1995b). Plants differed from animals, but there was a question about the reality of this difference. A negative relationship between $N_{e} / N$ and $\log N$ has been found in Drosophila, Triboilum, and the plant Eichbornia paniculata (Nozawa 1963, 1970; Husband \& Barrett 1992; Pray et al. in preparation). The range of $N_{e}$ is less than that for $N ; N_{e} / N$ estimates that include all relevant variables average 0.11 (Frankham 1995b). A model of mildly deleterious and neutral alleles and the negative relationship of $N_{\mathrm{e}} / N$ and $\log N$ seem to provide the most plausible reasons for the nonsigmoid relationship between heterozygosity and $\log N$. In conclusion, genetic varia- 
tion within species and among species is positively correlated with population size, confirming and amplifying the analysis of Soulé (1976).

This work provides compelling empirical support for conservation concerns about the genetic consequences of small population size. Theoretical prediction that reductions in population size reduce genetic variation have been amply verified. Consequently, reduction in population size will compromise the ability of populations to adapt genetically to changing environments.

\section{Acknowledgments}

I thank D. Cooper, P. England, D. Gilligan, L. Harder, M. Montgomery, A. Shapcott, D. Spielman, P. Sunnucks, A. Taylor, and L. Woodworth for comments on the manuscript, and $B$. Husband and $S$. Barrett for permission to refer to their unpublished results. My research is supported by research grants from the Australian Research Council and Macquarie University. This is publication no. 191 of the Key Centre for Biodiversity and Bioresources.

\section{Literature Cited}

Aquadro, C. F., and C. W. Kilpatrick. 1981. Morphological and biochemical variation and differentiation in insular and mainland deer mice (Peromyscus maniculatus). Pages 214-230 in M. H. Smith and J. Joule, editors. Mammalian population genetics. University of Georgia Press, Athens.

Arnquist, G., and D. Wooster. 1995. Meta-analysis: synthesizing research findings in ecology and evolution. Trends in Ecology and Evolution 10:236-240.

Avise, J. C. 1992. Molecular population structure and the biogeographic history of a regional fauna; a case history with lessons for conservation biology. Oikos 63:62-76.

Barrowclough, G. F., and G. F. Shields. 1984. Karyotypic evolution and long-term effective population sizes of birds. Auk 101:99-102.

Bijlsma, R., N. J. Ourborg, and R. van Treuren. 1994. On genetic erosion and population extinction in plants: a case-study with Scahtosa columbaria and Salvia pratensis. Pages 255-271 in V. Loeschcke, J. Tomiuk and $\mathrm{S}$. K. Jain, editors. Conservation genetics. Birkhäuser, Basel, Switzerland.

Billington, H. L. 1991. Effects of population size on genetic variation in a dioecious conifer. Conservation Biology 5:115-119.

Briscoe, D. A., J. M. Malpica, A. Robertson, G. J. Smith, R. Frankham, R. G. Banks, and J. S. F. Barker. 1992. Rapid loss of genetic variation in large captive populations of Drosophila files: implications for the genetic management of captive populations. Conservation Biology 6:416-425.

Brookfield, J. F. Y., and P. M. Sharp. 1994. Neutralism and selectionism face up to DNA data. Trends in Genetics 10:109-111.

Coates, D. J. 1988. Genetic diversity and population genetic structure in the rare Chittering grass wattle Acacia anomala Court. Australian Journal of Botany 36:273-286.

Coyne, J. A. 1984. Correlation between heterozygosity and rate of chmomosomal evolution in animals. American Naturalist 123:725-729.

Crow, J. F., and M. Kimura. 1970. An introduction to population genetics theory. Harper and Row, New York.

Descimon, H., and M. Napolitano. 1993. Enzyme polymorphism, wing pattern variability, and geographic isolation in an endangered butterfly species. Biological Conservation 66:117-123.

Dixon, P. M., and B. May. 1990. Genetic diversity and population struc- ture of a rare plant, Northern Monkshood (Aconitum noveboracense). New York State Museum Bulletin 471:167-175.

Dolan, R. W. 1994. Pattems of isozyme variation in relation to population size, isolation, and phytogeographic history in royal catchfly (Stlene regia; Caryophyllaceae). American Journal of Botany 81:965-972.

Eisen, E. J. 1975. Population size and selection intensity effects on long-term selection response in mice. Genetics 79:305-323.

Elstrand, N. C., and D. R. Elam. 1993. Population genetic consequences of small population size: implications for plant conservation. Annual Review of Ecology and Systematics 24:217-242.

Falconer, D. S., and T. F. C. Mackay. 1996. Introduction to quantitative genetics. 4th edition. Longman, Harlow, United Kingdom.

Fitzsimmons, N. N., S. W. Buskirk, and M. H. Smith. 1995. Population history, genetic variability, and horn growth in bighorn sheep. Conservation Biology 9:314-323.

Fos, M., A. Dominguez, A. Latorre, and A. Moya. 1990. Mitochondrial DNA evolution in experimental populations of Drosopbila subob scura. Proceedings of the National Academy of Sciences, USA 87: 4198-4201.

Frankham, R. 1995a. Conservation genetics. Annual Review of Genetics 29:305-327.

Frankham, R. 1995b. Effective population size/adult population size ratios in wildife: a review. Genetical Research 66:95-107.

Frankham, R. 1996a. Modeling problems in conservation genetics us ing laboratory animals. In press. In S. Ferson, editor. Quantitative methods in conservation biology. Springer-Verlag, New York.

Frankham, R. 1996b. Do island populations have less genetic variation than mainland populations? Heredity In press.

Frankham, R., L. P. Jones, and J. S. F. Barker. 1968. The effect of population size and selection intensity in selection for a quantitative character in Drosophila. I. Short-term response to selection. Genetical Research 12:237-248.

Franklin, I. R. 1980. Evolutionary change in small populations. Pages 135-149 in M. E. Soulé and B. A. Wilcox, editors. Conservation biology: an evolutionary-ecological perspective. Sinauer Associates, Sunderiand, Massachusetts.

Gilbert, D. A., N. Lehman, S. J. O'Brien, and R. K. Wayne. 1990. Genetic fingerprinting reflects population differentiation in the California Channel istand fox. Nature 344:764-767.

Gill, A. E. 1980. Evolutionary genetics of California Island Peromyscus. Pages $719-743$ in D. M. Power, editor. The California islands: proceedings of a multidisciplinary symposium. Santa Barbara Muscum of Natural History, Santa Bartara, California.

Gillespie, J. H. 1991. The causes of molecular evolution. Oxford University Press, New York.

Gorman, G. L., M. E. Soulé, S. Y. Yang, and E. Nevo. 1975. Evolutionary genetics of insular Adriatic lizards. Evolution 29:52-71.

Hammond, K. 1973. Population size, selection response and variation in quantitative inheritance. Ph.D. thesis. University of Sydney, Sydney.

Hamrick, J. L., and M. J. W. Godt. 1989. Allozyme diversity in plant species. Pages 43-63 in A. H. D. Brown, M. T. Clegg, A. L. Kahler, and B. S. Weir, editors. Plant population genetics, breeding, and genetic resources. Sinatier Associates, Sunderland, Massachusetts.

Hedrick, P. W. 1986. Genetic polymorphism in heterogeneous environments: a decade later. Annual Review of Ecology and Systematics 17:535-566.

Husband, B. C., and S. C. H. Barrett. 1992. Effective population size and genetic drift in tristylous Eicbbornia paniculata (Pontederiaceae). Evolution 46:1875-1890.

Hutter, C. M., and D. M. Rand. 1995. Competition between mitochondrial haplotypes in distinct nuclear genetic environments: Dro sophila pseudoobscura vs. D. persimilis. Genetics 140:537-548.

Jones, L. P., R. Frankham, and J. S. F. Barker. 1968. The effects of population size and selection intensity in selection for a quantitative character in Drosopbila. II. Long-term response to selection. Genetical Research 12:249-266.

Karron, J. D. 1987. A comparison of levels of genetic polymorphism 
and self-compatibility in geographically restricted and widespread plant congeners. Evolutionary Ecology 1:47-58.

Kawamoto, Y., K. Nozawa, K. Matsubayashi, and S. Gotoh. 1988. A population-genetic study of crab-eating macaques (Macaca fascicularis) on the island of Angaur; Palau, Micronesia. Folia Primatolog ica 51:169-181.

Kilpatrick, C. W. 1981. Genetic structure of insular populations. Pages 28-59 in M. H. Smith and J. Joule, editors. Mammalian population genetics. University of Georgia Press, Athens.

Kimura, M. 1983. The neutral theory of molecular evolution. Cambridge University Press, Cambridge, United Kingdom.

Lande, R. 1979. Effective deme size during long-term evolution estimated from rates of chromosomal rearrangement, Evolution 33: 234-251

MacRae, A. F., and W. W. Anderson. 1988. Evidence for non-neutrality of mitochondrial DNA haplotypes in Drosopbila pseudoobscura. Genetics 120:485-494.

McClenaghan, L. R. J., and A. C. Beauchamp. 1986. Low genetic differentiation among isolated populations of the California fan palm (Washingtonia filfera). Evolution 40:315-322.

McNeely, J. A., K. R. Miller, W. V. Reid, R. A. Mittermeier, and T. B Werner. 1990. Conserving the world's biological diversity. IUCN, Gland, Switzerland.

Moran, G. F., and S. D. Hopper. 1983. Genetic diversity and the insular population structure of the rare granite rock species, Eucalyptus caesia Benth. Australian Journal of Botany 31:161-172.

Moran, G. F., and S. D. Hopper. 1987. Conservation of the genetic re sources of rare and widespread eucalypts in remnant vegetation. Pages 151-162 in D. A. Saunders, G. W. Amoid, A. A. Burbidge, and A. J. M. Hopkins, editors. Nature conservation: the role of remnants of native vegetation. Surrey Beatty, Chipping Norton, New South Wales, Australia.

Nei, M., and D. Graur. 1984. Extent of protein polymorphism and the neutral mutation theory. Evolutionary Biology 17:73-118.

Nevo, E., A. Bieles, and R. Ben-Shlomo. 1984. The evolutionary significance of genetic diversity: ecological, demographic and life history correlates. Pages 13-213 in G. S. Mani, editor. Evolutionary dynamics of genetic diversity. Springer-Verlag, Berlin, Germany.

Nozawa, K. 1963. Competition between brown gene and its wild-type allele in Drosophila melanogaster. II. Estimation of relative viability of brown homozygotes and an analysis of changes in gene-frequency. Japanese Journal of Genetics 38:6-20.

Nozawa, K. 1970. Estimation of the effective size in Drosophila experimental populations. Drosphila Information Service 45:117-118.

Ohta, T. 1992. The near neutral theory of molecular evolution. Annual Review of Ecology and Systematics 23:263-286.

Patton, J. L. 1984. Genetical processes in the Galapagos. Biological Journal of the Linnean Society 21:97-111.

Patton, J. L., and S. Y. Yang. 1977. Genetic variation in Thomomys bottae pocket gophers: microgeographic patterns. Evolution 31:697-720.

Patton, J. L., S. Y. Yang, and P. Myers. 1975. Genetic and morphological divergence among introduced rat populations (Rattus rattus) of the Galapagos archipelago, Ecuador. Systematic Zoology 24:296-310.

Peters, G. B., J. S. Lonie, and G. F. Moran. 1980. The breeding system, genetic diversity and polien sterility in Eucalyptus pulverulenta, a rare species with small disjunct populations. Australian Journal of Botany 38:559-570.

Peterson, A. T., P. Escalante, and S. A. Navarro. 1992. Genetic variation and differentiation in Mexican populations of Common Bush-tanagers and Chesnut-capped Brush-finches. Condor 94:244-252.

Peterson, A. T., and L. R. Heaney. 1993. Genetic differentiation in Philippine bats of the genera Cyanoptersu and Haplonycteris. Biological Journal of the Linnean Society 49:203-218.

Prober, S. M., and A. H. D. Brown. 1994. Conservation of the grassy white box woodlands: population genetics and fragmentation of Eucalyptus albens. Conservation Biology 8:1003-1013.
Prober, S. M., C. Tompkins, G. F. Moran, and J. C. Bell. 1990. The conservation genetics of Eucalyptus paliformis L. Johnson et Blaxell and $E$. parvifolia Cambage, two rare species from south-eastem Australia. Australian Journal of Botany 38:79-95.

Raijmann, L. E. L., N. C. Van Leeuwan, R. Kersten, J. R. B. Oostermeijer, H. C. M. Den Nijs, and S. B. J. Menken. 1994. Genetic variation and outcrossing rate in relation to population size in Gentiana pmeumonanthe L. Conservation Biology 8:1014-1026.

Ralls, $K_{\text {, }}$ and J. Ballou. 1983. Extinction: lessons from zoos. Pages 164184 in C. M. Schonewald-Cox, S. M. Chambers, B. MacBryde, and W. L. Thomas, editors. Genetics and conservation: a reference for managing wild animal and plant populations. Benjamin/Cummings, Menlo Park, California.

Robertson, A. 1962. Selection for heterozygotes in small populations. Genetics 47:1291-1300.

Sampson, J. F., S. D. Hopper, and S. H. James. 1988. Genetic diversity and the conservation of Eucalyptus crucis Maiden. Australian Journal of Botany 36:447-460.

Sarre, S., T. D. Schwaner, and A. Georges. 1990. Genetic variation among insular populations of the sleepy lizard, Trackydosaurus rugosus Gray (Squamata: Scincidae). Australian Journal of Zoology 38:602-616

Satta, Y., C. O'hUigin, N. Takahata, and J. Klein. 1994. Intensity of natural selection at the major histocompatibility complex loci. Proceedings of the National Academy of Sciences, USA 91:7184-7188.

Saura, A., O. Halkka, and J. Lokki. 1973. Enzyme gene heterozygosity in small island populations of Pbilaenus spumarius (L.) (Homoptera). Genetica 44:459-473.

Shapcott, A. 1994. Genetic and ecological variation in Atberosperma moschatum and the implications for conservation of its biodiversity. Australian Joumal of Botany 42:663-686.

Silvela, L, R. Rodgers, A. Barrera, and D. E. Alexander. 1989. Effect of selection intensity and population size on percent oil in maize, Zea mays L. Theonetical and Applied Genetics 78:298-304.

Soulé, M. E. 1972. Phenetics of natural populations. HI. Variation in insular populations of a lizard. American Naturalist 106:429-446.

Soulé, M. E. 1976. Allozyme variation, its determinants in space and time. Pages $60-77$ in F. J. Ayala, editor. Molecular evolution. Sinauer Associates, Sunderland, Massachusetts.

Soulé, M. E. 1980. Thresholds for survival: maintaining fitness and evolutionary potential. Pages 151-169 in M. E. Soulé and B. A. Wilcox, editors. Conservation biology: an evolutionaryecological perspective. Sinauer Associates, Sunderland, Massachusetts.

Soulé, M. E., and S. Y. Yang. 1973. Genetic variation in side-blotched lizards in the Gulf of Califomia. Evolution 27:593-600.

Stangel, P. W., M. R. Lennartz, and M. H. Smith. 1992. Genetic variation and population structure of Red-cockaded Woodpeckers. Conservation Biology 6:283-292.

Wauters, L. A., Y. Hutchinson, D. T. Parkin, and A. A. Dhondt. 1994. The effect of habitat fragmentation on demography and on the loss of genetic variation in the red squirrel. Proceedings of the Royal Society of London B 255:107-111.

Weaver, R. F., and P. W. Hedrick. 1992. Genetics. 2nd edition. Wm. C. Brown, Dubuque, Iowa.

Weber, K. E. 1990. Increased selection response in larger populations I. Selection for wing-tip height in Drosophila melanogaster at three population sizes. Genetics 125:579-584.

Weber, K. E., and L. T. Diggins. 1990. Increased selection response in larger populations. II. Selection for ethanol vapor resistance in Drosopbila melanogaster, at two population sizes. Genetics 125:585-597.

Wooten, M. C., and M. H. Smith. 1985. Large mammals are genetically less variable. Evolution 39:210-212.

Wright, S. 1931. Evolution in Mendelian populations. Genetics 16: 97-159.

Yang, S. Y, and J. L. Patton. 1981. Genetic variability and differentiation in the Galapagos finches. Auk 98:230-242. 